\title{
Regulation of Interferon Receptor Expression in Human Blood Lymphocytes In Vitro and during Interferon Therapy
}

\author{
Allan S. Lau,* Gregory E. Hannigan," Melvin H. Freedman,‡ and Bryan R. G. Williams*§ \\ ${ }^{*}$ Division of Infectious Diseases and $\ddagger$ Division of Hematology/Oncology, Research Institute, The Hospital for Sick Children, \\ Toronto, M5G 1X8; and §Department of Medical Genetics, University of Toronto, Canada
}

\begin{abstract}
Interferons (IFN) elicit antiviral and antineoplastic activities by binding to specific receptors on the cell surface. The binding characteristics of IFN to human lymphocytes were studied using IFN $\alpha_{2}$ labeled with ${ }^{125}$ I to high specific activity. The specific binding curves generated were analyzed by the LIGAND program of Munson and Rodbard to determine receptor numbers. The number of receptors in peripheral blood lymphocytes (PBL) and tonsillar B-lymphocytes (TBL) from normal individuals were $505 \pm 293(n=10)$ and $393 \pm 147(n=3)$ respectively. When these cells were preincubated in vitro with unlabeled IFN $\alpha_{2}$, the receptor number decreased to $82 \pm 45$ and $61 \pm 16$ respectively. Receptor binding activities recovered gradually over a period of $72 \mathrm{~h}$ when the cells were incubated in IFN-free medium. This recovery of receptors could be blocked by the addition of actinomycin $D$ to the incubation medium. A similar decrease in receptor expression was observed in vivo in PBL from patients being treated daily with $5 \times 10^{6}$ units $/ \mathrm{m}^{2}$ per $d$ of IFN $\alpha_{2}$ by subcutaneous injection, for acute lymphoblastic leukemia or papilloma virus infections. Receptor numbers in PBL in vivo were further reduced concurrent with the progression of IFN therapy. Thus the reduction in IFN receptor expression observed in vitro can be demonstrated in vivo. These studies indicate that monitoring IFN receptor expression in vivo can provide information regarding the availability of IFN receptors at the cell surface for the mediation of IFN actions during the course of IFN therapy.
\end{abstract}

\section{Introduction}

The interferons (IFN) ${ }^{1}$ are a group of proteins which regulate a wide spectrum of cell functions and modulate responses to infectious and malignant diseases $(1,2)$. Since the discovery of IFN, there has been intensive interest in the application of the modulators for clinical use as both antiviral and antineoplastic agents (3). Recent advances in recombinant DNA technology

Address correspondence and reprint requests to Dr. Williams, Department of Pediatrics, Division of Infectious Diseases, The Hospital for Sick Children, 555 University Avenue, Toronto, Ontario, Canada M5G 1 X8.

Received for publication 8 August 1985 and in revised form 25 November 1985 .

1. Abbreviations used in this paper: IFN, human interferon; PBL, peripheral blood lymphocytes; SDS-PAGE, sodium dodecyl sulfate-polyacrylamide gel electrophoresis; TBL, tonsillar B lymphocytes.

J. Clin. Invest.

(C) The American Society for Clinical Investigation, Inc.

0021-9738/86/05/1632/07 \$1.00

Volume 77, May 1986, 1632-1638 in addition to supplying IFN for clinical trials, have also provided IFN preparations of sufficiently high purity to allow radioreceptor assays.

The interaction of IFN with susceptible cells is mediated by binding to specific high affinity cell surface receptors, a step which is necessary for the subsequent biological effects of IFN (4). Cellular processes subsequent to the binding of IFN show general similarities with many other polypeptide hormone-receptor systems such as insulin or epidermal growth factor $(5,6)$. Interferonreceptor complexes are internalized and degraded intracellularly subsequent to ligand binding $(7,8)$. Therefore IFN can modulate the expression of its own receptor in target cells. This phenomenon of ligand-induced down-regulation of IFN receptors has been observed in Daudi (lymphoblastoid), WISH (human amnion), and other cultured cell lines (9-12). In addition, we have described the desensitization of IFN $\alpha$ receptors by treatment of a human cell line with IFN $\gamma$ (13). This clearly results from an indirect mechanism since IFN $\alpha$ and $\gamma$ do not share the same receptor sites (14).

The regulation of IFN receptors by IFN itself has important implications for the clinical use of IFN. The current use of IFN in patients often involves empiric choice of dosage and dosing interval. The optimal dose of IFN necessary to elicit in vivo cellular responses to treatment is not known. In order to further evaluate the therapeutic potential of IFN, it is important to study cellular responses, including the regulation of IFN receptors during IFN therapy.

In the present study, we have investigated the expression of IFN receptors on freshly isolated blood lymphocytes from normal individuals and from patients on IFN therapeutic trials for acute lymphoblastic leukemia and papilloma virus infection. The phenomenon of down-regulation of IFN $\alpha$ receptors by IFN $\alpha_{2}$ itself was demonstrated both in vitro and in vivo.

\section{Methods}

Isolation of cells. Peripheral blood lymphocytes (PBL) were isolated from healthy volunteers using Ficoll-Hypaque density gradient centrifugation as described (15). Washed PBL were resuspended in RPMI 1640 medium supplemented with $2 \%$ fetal calf serum (Gibco, Grand Island, NY), and containing, per $\mathrm{ml}, 100 \mathrm{U}$ of penicillin and $100 \mu \mathrm{g}$ of streptomycin. Tonsillar B-lymphocytes (TBL) were isolated from tonsils (obtained at elective tonsillectomies), and finely minced with a scalpel. The resulting cell suspensions were centrifuged over Ficoll-Hypaque, and the tonsillar lymphocytes obtained were depleted of $T$ lymphocytes by rosetting with neuraminidase-treated sheep erythrocytes as described (16). The cells were suspended in RPMI medium and incubated in a tissue culture dish (Falcon) at $37^{\circ} \mathrm{C}$ for $30 \mathrm{~min}$ for monocyte depletion. The lymphocytes isolated were incubated in RPMI medium with the addition of indicated concentrations of IFN $\alpha_{2}$ (Schering Corp., Bloomfield, NJ) for $18 \mathrm{~h}$ or as denoted in the figure legends. Cells left untreated with IFN were incubated for the same period of time and used as controls. Subsequent 
to the incubation period, the cells were washed with fresh medium and used for binding and affinity-labeling experiments, as described below.

To account for the possibility that prior occupancy of cellular IFN $\alpha$ receptors (by unlabeled IFN $\alpha_{2}$ in the pretreatment procedure) might be inhibiting the subsequent receptor assay with ${ }^{125}$ I-IFN $\alpha_{2}$, the following experiments were performed. After incubation at $37^{\circ} \mathrm{C}$ for $18 \mathrm{~h}$ with $1,000 \mathrm{U} / \mathrm{ml}$ of IFN $\alpha_{2}$, the cells were washed with acidic phosphatebuffered saline (PBS) (pH 5.5) for $8 \mathrm{~min}$ to release receptor-bound unlabeled IFN $\alpha_{2}(10)$. Cells not treated with unlabeled IFN $\alpha_{2}$ were used as controls. All cells were assayed for ${ }^{125}$ I-IFN $\alpha_{2}$ receptor binding as described.

In vivo studies were done on $\mathrm{PBL}$ isolated from patients being treated with IFN $\alpha_{2}$ (Schering Corp.), $5 \times 10^{6} \mathrm{U} / \mathrm{m}^{2}$ per $\mathrm{d}$ daily by subcutaneous injection for acute lymphoblastic leukemia or papilloma virus infections. The binding of ${ }^{125}$ I-IFN $\alpha_{2}$ to the patients' PBL were monitored prior to and during the course of IFN therapy. Heparinized blood samples were taken from these patients $20 \mathrm{~h}$ after IFN injection on designated days during therapy.

Iodination of IFN. The binding of IFN to lymphocytes was studied using IFN $\alpha_{2}$ (kindly provided by Drs. P. Trotta and T. Nagabhushan, Schering Corp, sp act $2 \times 10^{8} \mathrm{IU} / \mathrm{mg}$ protein) labeled to high specific activity $(90-120 \mathrm{Ci} / \mathrm{g})$ with ${ }^{125} \mathrm{I}$ by a solid-phase lactoperoxidase procedure (17). The specific activity of monoiodinated IFN (indicative of $100 \%$ mean incorporation) is determined to be $110 \mathrm{Ci} / \mathrm{g}$. The iodinated IFN was separated from unincorporated ${ }^{125}$ I by chromatography in a Sephadex G-50 column, $0.7 \times 18 \mathrm{~cm}$, as described previously (17). The ${ }^{125}$ I-IFN $\alpha_{2}$ eluted was titrated for antiviral activity against National Institute of Allergy and Infectious Diseases reference standard G-023-901-527 (10). All units are expressed as international units.

Cellular binding assay. Cultured or freshly isolated lymphocytes were washed and suspended in RPMI-1640 medium containing 2\% fetal calf serum. Binding reactions were carried out in $200 \mu \mathrm{l}$ volumes containing $4 \times 10^{5}$ cells and the indicated concentrations of ${ }^{125} \mathrm{I}$-IFN $\alpha_{2}$, in triplicates (17). After incubation for $4 \mathrm{~h}$ at $4^{\circ} \mathrm{C}$ the reactions were quickly layered over $150 \mu \mathrm{l}$ of a phthalate oil mixture in a $1.5-\mathrm{ml}$ conical microfuge tube, and centrifuged for $30 \mathrm{~s}$ at $12,500 \mathrm{~g}$ in an Eppendorf model 5414 microfuge. The culture medium and phthalate oil were then aspirated and cell pellet analysed for cell-bound radioactivity on a Beckman 5500 Gamma Counter. Binding specificity was determined in parallel incubations including a 100-fold excess of unlabeled IFN $\alpha_{2}$ at each ${ }^{125}$ I-IFN $\alpha_{2}$ concentration. The nonspecific counts obtained were subtracted from total counts bound to obtain the specific binding activities reported. All bindings are reported as specific counts bound.

Recovery of IFN receptor expression. Freshly isolated TBL in RPMI medium were treated with $1,000 \mathrm{U} / \mathrm{ml}$ of IFN $\alpha_{2}$ for $3 \mathrm{~h}$ at $37^{\circ} \mathrm{C}$, or left untreated. The cells were washed and allowed to recover in IFN-free RPMI medium. At indicated time intervals, aliquots of $5 \times 10^{6}$ cells were taken for binding reactions and crosslinking experiments with ${ }^{125} \mathrm{I}$ IFN $\alpha_{2}$ described below. In addition, $5 \times 10^{6}$ cells were taken for retreatment with $1,000 \mathrm{U} / \mathrm{ml}$ of IFN $\alpha_{2}$, at $37^{\circ} \mathrm{C}$ for $3 \mathrm{~h}$, at the end of the 22-h recovery incubation. The controls were cells incubated and washed in the same manner but without any IFN $\alpha_{2}$ treatment.

Effect of actinomycin $D$. In another experiment, freshly isolated PBL were similarly pretreated with $1,000 \mathrm{U} / \mathrm{ml}$ of IFN $\alpha_{2}$ at $37^{\circ} \mathrm{C}$ for $3 \mathrm{~h}$. The cells were washed with acidic PBS (pH 5.5) to dissociate any prebound unlabeled IFN $\alpha_{2}$. The cells were allowed to recover in IFN-free RPMI medium for $22 \mathrm{~h}$ at $37^{\circ} \mathrm{C}$ with or without the presence of actinomycin $\mathrm{D}$ at $1 \mu \mathrm{g} / \mathrm{ml}$. Cellular binding assays and affinity-labeling experiments as described were performed on these cells. Cells not treated with IFN $\alpha_{2}$ or actinomycin D, but washed with acidic PBS (pH 5.5), were used as controls.

Affinity labeling of IFN receptors. Subsequent to the incubations outlined above, binding reactions were carried out at $4^{\circ} \mathrm{C}$ with $5 \times 10^{6}$ cells in $500 \mu \mathrm{l}$ volumes containing $50 \mathrm{ng} / \mathrm{ml}$ of ${ }^{125} \mathrm{I}-\mathrm{IFN} \alpha_{2}$, under conditions as described in the cell binding section. Cells were washed three times in cold PBS, resuspended in $1 \mathrm{ml}$ of PBS containing $1 \mathrm{mM}$ dissuccinimidyl suberate, and incubated for $30 \mathrm{~min}$ at $4^{\circ} \mathrm{C}$. Cells were subsequently washed in PBS. Lysis of the cells was performed in a Tris buffer ( $\mathrm{pH} 7.5$,
$50 \mathrm{mM}$ ) containing $0.5 \% \mathrm{NP}-40,7 \mathrm{mM}$ magnesium acetate, $90 \mathrm{mM}$ potassium chloride, and $150 \mathrm{mM}$ glucose. $1 \mathrm{mM} \mathrm{1,10-phenanthroline,}$ $1 \mathrm{mM}$ benzamidine, $2 \mathrm{mM}$ sodium metabisulphite, $50 \mu \mathrm{M}$ phenylmethylsulfonyl fluoride, $50 \mu \mathrm{g} / \mathrm{ml}$ crude soybean trypsin inhibitor and 50 $\mu \mathrm{g} / \mathrm{ml}$ aprotinin were added to the lysis buffer as protease inhibitors (17a). After $1 \mathrm{~h}$ of incubation on ice with frequent vortexing, the extract was centrifuged at $12,500 \mathrm{~g}$ for $10 \mathrm{~min}$, in an Eppendorf microfuge. The supernatants $(20-25 \mu \mathrm{l})$ were mixed with an equal volume of electrophoresis buffer (containing $1 \mathrm{mM}$ dithiothreitol and 2-mercaptoethanol), boiled for $5 \mathrm{~min}$, and subjected to sodium dodecyl sulphate-polyacrylamide gel electrophoresis (SDS-PAGE) using 7.5\% gels (18). Gels were dried under vacuum, and exposed to XAR film (Eastman Kodak Co., Rochester, NY) with lightening-plus intensifying screens (DuPont Co., Wilmington, DE) for $8 \mathrm{~d}$ at $-70^{\circ} \mathrm{C}$.

Analysis of binding data. Specific ${ }^{125} \mathrm{I}-\mathrm{IFN} \alpha_{2}$ binding data were used to determine receptor numbers and dissociation constant, $K_{\mathrm{D}}$. With the increasing concentrations of ${ }^{125} \mathrm{I}-\mathrm{IFN} \alpha_{2}$ in the cellular binding reaction, respective specific binding activities corresponding to each ${ }^{125} \mathrm{I}-\mathrm{IFN} \alpha_{2}$ concentration were calculated. These specific binding data were plotted according to the method of Scatchard $(18,19)$, and in addition, analyzed by the LIGAND program of P. Munson and D. Rodbard (20). An applesoft version of the LIGAND program adapted by $T$. Jackson and $P$. Edwards of Middlesex Hospital, London, England, was employed. The program resolves the equations describing the laws of mass-action binding, and objectively allows the determination of both the number of receptors and the $K_{\mathrm{D}}$, characterizing the binding reaction.

\section{Results}

Expression of IFN receptors on lymphocytes. Specific binding curves were generated when PBL and TBL from normal individuals were incubated at $4^{\circ} \mathrm{C}$ for $4 \mathrm{~h}$ in the presence of increasing concentrations of ${ }^{125}$ I-IFN $\alpha_{2}$ (Figs. 1 and 2). A Scatchard plot of these data indicates a linear interaction of ${ }^{125} \mathrm{I}$-IFN $\alpha_{2}$ with its receptors (insets of Figs. 1 and 2). The LIGAND program of $P$. Munson was used to determine the number of receptors expressed on the lymphocytes. Normal PBL (Fig. 1) exhibit receptors of $K_{\mathrm{D}}=1 \times 10^{-9} \mathrm{M}, 700$ sites/cell, and normal TBL possess receptors of $K_{\mathrm{D}}=9.3 \times 10^{-10} \mathrm{M}, 504$ sites/cell. Data from PBL freshly isolated from 10 individuals and TBL from three individuals are compiled in Table I. Normal PBL exhibit an average of $505 \pm 293$ sites (range 204-900, $n=.10$ ) per cell with $K_{\mathrm{D}}=7.6 \pm 5.0 \times 10^{-10} \mathrm{M}$, whereas normal TBL possess $393 \pm 147$ sites (range $227-504, n=3$ ) per cell with $K_{\mathrm{D}}=5.7 \pm 3.5$ $\times 10^{-10} \mathrm{M}$. The $K_{\mathrm{D}}$ is practically defined as the concentration of ligand (IFN) that is required to saturate $50 \%$ of the receptor sites on the cell surface.

Down-regulation of IFN receptor expression. To evaluate the effect of in vitro incubation on receptor binding of PBL, cells were incubated for $18 \mathrm{~h}$ at $37^{\circ} \mathrm{C}$ in the absence of IFN. Subsequent receptor binding assays did not show any significant loss of receptor sites/cell, i.e., $488 \pm 181$ (range 225-800, $n=7$ ). However, on pretreatment of PBL or TBL with unlabeled IFN $\alpha_{2}\left(1,000 \mathrm{U} / \mathrm{ml}\right.$, at $37^{\circ} \mathrm{C}$ for $\left.18 \mathrm{~h}\right)$ there was a marked and reproducible reduction in subsequent receptor expression as measured by ${ }^{125}$ I-IFN $\alpha_{2}$ binding. This phenomenon of down-regulation is observed in both cell types with receptor numbers decreased to 90 sites per cell from a level of 700 sites per cell in PBL (Fig. $1 \dot{A}$ ), and to 78 sites per cell from a level of 504 sites per cell in TBL (Fig. 2). Data from IFN pretreatment of PBL isolated from six individuals and TBL isolated from three individuals are shown (Table I). The percent in reduction ranged between $60 \%$ and $90 \%$. A similar level of reduction in binding 

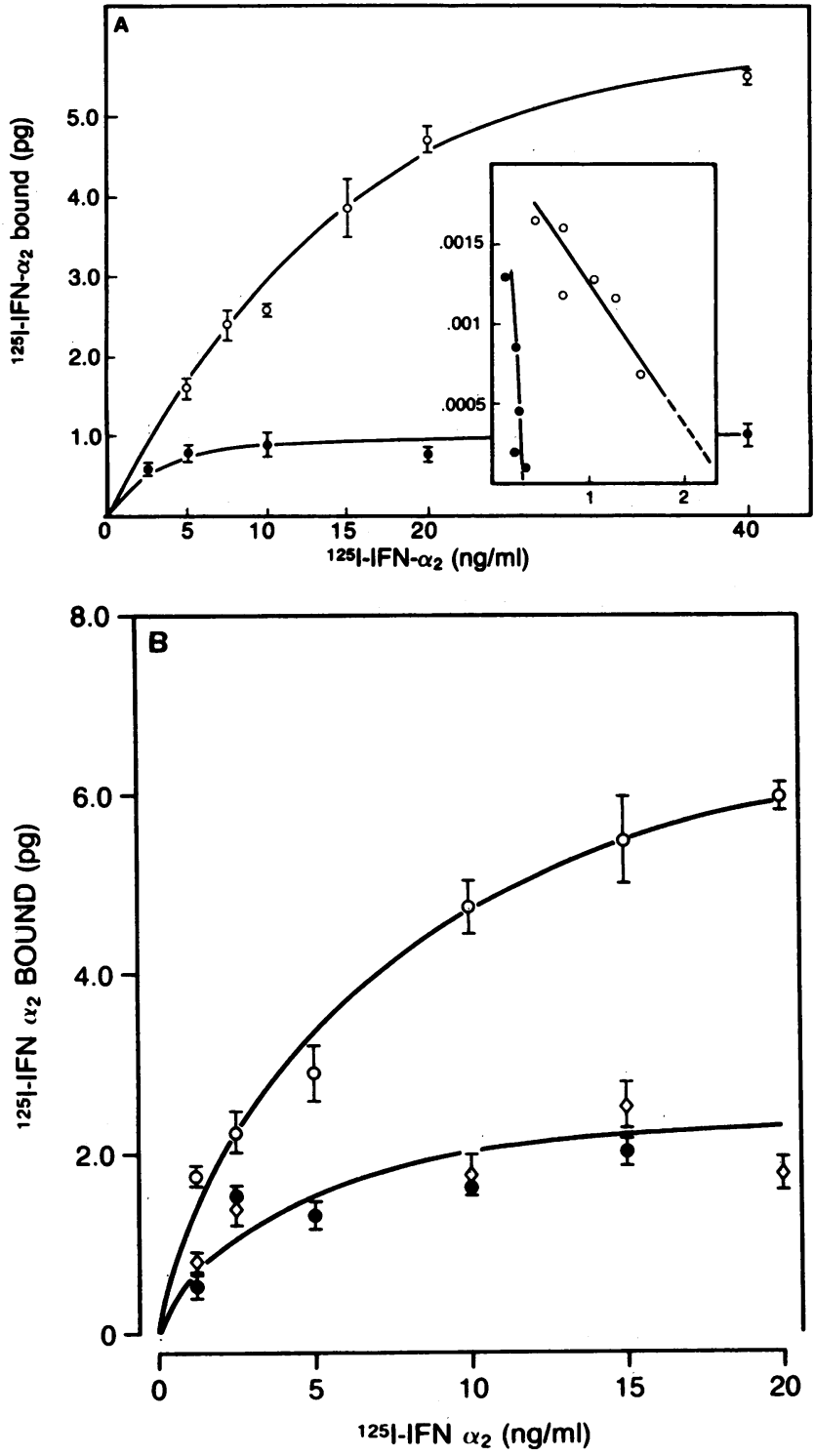

Figure 1. In vitro reduction in IFN $\alpha$ receptor binding in PBL with IFN $\alpha_{2}$ pretreatment. ( $A$ ) PBL were isolated as described in Methods. Cells were treated with IFN $\alpha_{2}, 1,000 \mathrm{U} / \mathrm{ml}$; at $37^{\circ} \mathrm{C}$ for $18 \mathrm{~h}$. Binding assays were performed with $4 \times 10^{5}$ cells in a volume of $200 \mu \mathrm{l}, 4 \mathrm{~h}$ at $4^{\circ} \mathrm{C}$, with the indicated concentrations of ${ }^{125} \mathrm{I}-\mathrm{IFN} \alpha_{2}$. As controls, parallel determinations were obtained on cells without IFN pretreatment. Linear and nonsaturable nonspecific binding represented, typically, 50\% of the total binding for both PBL and TBL. Each point represents the mean of triplicate incubations for each ${ }^{125}$ I-IFN $\alpha_{2}$ concentration, with error bars indicating one standard deviation about the mean. The Scatchard plot (inset with ordinate as ratio of bound to free ligand, and abscissa as pM bound) is illustrative of the curves resolved by LIGAND. These curves are representative of the data compiled in Table I. O, Control; •, IFN pretreated. (B) PBL were pretreated with IFN $\alpha_{2}(1,000 \mathrm{U} / \mathrm{ml})$ as in $(A)$. Cells were subsequently washed with PBS (pH 7.4), or PBS titrated to acidic pH (5.5) to dissociate prebound unlabeled IFN $\alpha_{2} . \circ$, Control; •, IFN pretreated; $\diamond$, IFN pretreated plus acidic $\mathrm{pH}$ wash.

of ${ }^{125}$ I-IFN $\alpha_{2}$ was also observed when cells were pretreated with unlabeled IFN $\alpha_{2}$ for shorter periods of time (see below Figs. 4 and 6). With the use of lower concentrations of unlabeled IFN

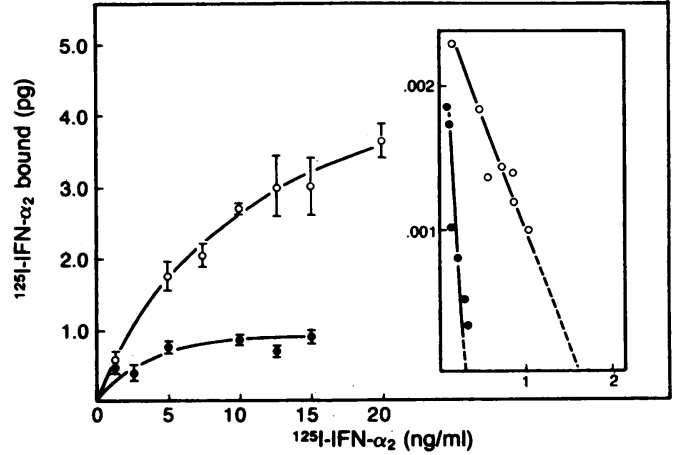

Figure 2. In vitro reduction in IFN $\alpha$ receptor binding in TBL with IFN $\alpha_{2}$ pretreatment. TBL were isolated as described in Methods. Cells were treated with IFN $\alpha_{2}$, and subsequent ${ }^{125}$ I-IFN $\alpha_{2}$ binding assays were performed as described in Fig. 1. Inset axis as in Fig. 1. 0 , Control; $\bullet$, IFN pretreated.

$\alpha_{2}$ in pretreatment, i.e., $50 \mathrm{U} / \mathrm{ml}$ and $200 \mathrm{U} / \mathrm{ml}$, the reduction in binding is less pronounced than that observed with $1,000 \mathrm{U} /$ ml pretreatment (Fig. 3). At these lower pretreatment concentrations (Fig. 3), the receptor number decreased to $177 \pm 40$ and $195 \pm 60$ sites per cell, respectively. Thus the extent of reduction in subsequent ${ }^{125}$ I-IFN $\alpha_{2}$ binding was clearly dependent on the concentration of IFN $\alpha_{2}$ used in pretreatment.

We next considered the possibility that receptors at the cell surface might be significantly occupied by IFN $\alpha_{2}$ during the pretreatment procedure, thereby blocking subsequent assays for IFN $\alpha_{2}$ receptor expression. After pretreatment with unlabelled IFN $\alpha_{2}$, PBL were washed with acidic (pH 5.5) PBS prior to ${ }^{125}$ I-IFN $\alpha_{2}$ receptor binding assays. This procedure ensured that prebound IFN was released from cell surface receptors, without affecting subsequent receptor assays $(10)$. The results $(n=4)$ essentially showed identical specific binding curves and receptor sites as resolved by the LIGAND program, obviating the possibility of prior receptor occupancy in the observed downregulation. In a representative experiment (Fig. $1 B$ ), normal PBL showed $450 \pm 50$ sites/cells. PBL, pretreated with IFN $\alpha_{2}$, exhibited $177 \pm 22$ sites/cell, whereas pretreated PBL exposed to the acidic wash protocol exhibited $150 \pm 25$ sites/cell. Also, the acidic wash did not affect subsequent receptor binding assay on control cells (data not shown).

Table I. Receptor Numbers in Human Lymphocytes Untreated or Treated with IFN

\begin{tabular}{lcc}
\hline & \multicolumn{2}{l}{ Receptor sites per cell* } \\
\cline { 2 - 3 } & PBL & TBL \\
\hline Normal & $505 \pm 293$ & $393 \pm 147$ \\
& $(n=10)$ & $(n=3)$ \\
IFN treatment & $85 \pm 45$ & $61 \pm 16$ \\
& $(n=7)$ & $(n=3)$ \\
& $P<.001$ & $P<.02$
\end{tabular}

All binding experiments involved generation of complete isotherms at $4^{\circ} \mathrm{C}$. The binding data obtained were then analysed by LIGAND to determine receptor numbers.

* Mean of $n$ replicates \pm 1 SD. 


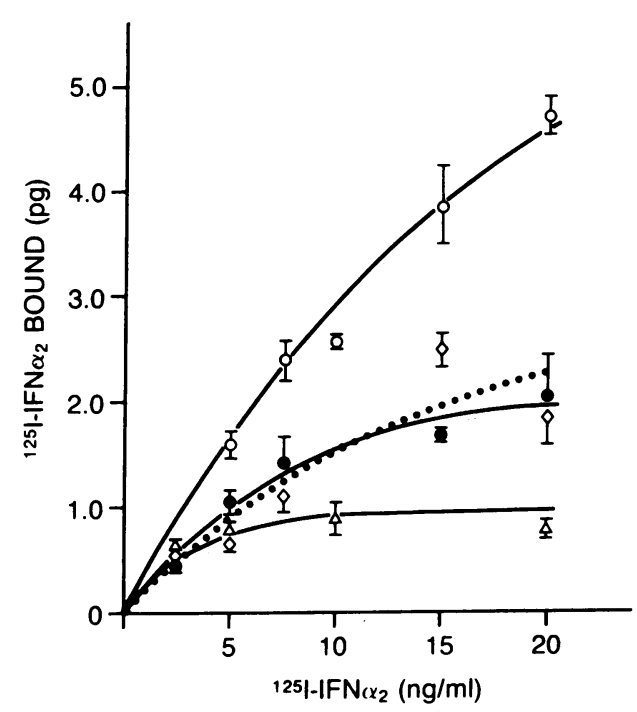

Figure 3. Dose response of IFN receptor binding in PBL pretreated with IFN $\alpha_{2}$. PBL were isolated as described in Methods. Cells were pretreated with different concentrations of unlabeled IFN $\alpha_{2}$, i.e., 50 $\mathrm{U} / \mathrm{ml}, 200 \mathrm{U} / \mathrm{ml}$, and $1,000 \mathrm{U} / \mathrm{ml}$, at $37^{\circ} \mathrm{C}$ for $18 \mathrm{~h}$. Subsequent to washings, ${ }^{125} \mathrm{I}$-IFN $\alpha_{2}$ binding assays were performed at $4^{\circ} \mathrm{C}$ as outlined in Methods. ०, Control; $\diamond$, IFN $50 \mathrm{U} / \mathrm{ml} ; \bullet$, IFN $200 \mathrm{U} / \mathrm{ml} ; \Delta$, $1,000 \mathrm{U} / \mathrm{ml}$.

Recovery of IFN receptor expression. The recovery of IFN binding activity can be best illustrated using a bifunctional crosslinking agent, disuccinimidyl suberate, which has been used previously to identify IFN binding cell-surface components (Fig. 4) $(21,22)$. When the crosslinking agent is added to cells pre-

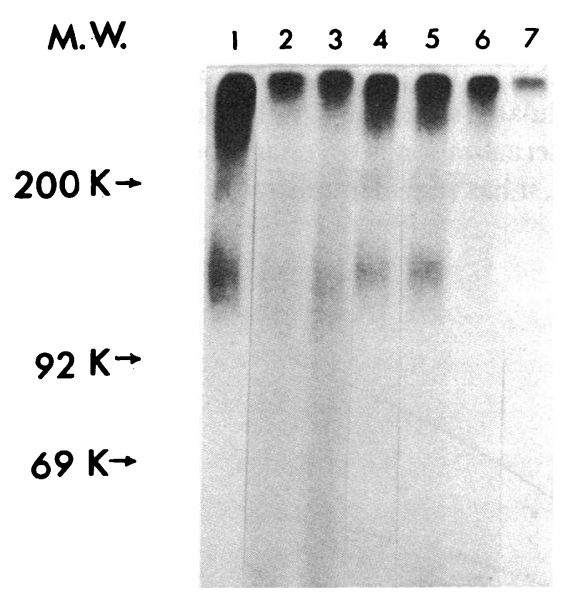

Figure 4. Affinity labeling of IFN receptors. Freshly isolated TBL were pretreated with $1,000 \mathrm{U} / \mathrm{ml}$ of IFN $\alpha_{2}$ for $3 \mathrm{~h}$ at $37^{\circ} \mathrm{C}$. These cells were washed and allowed to recover in IFN-free RPMI medium. At indicated time intervals, aliquots of $5 \times 10^{6}$ cells were taken for binding with $50 \mathrm{ng} / \mathrm{ml}$ of ${ }^{125} \mathrm{I}-\mathrm{IFN} \alpha_{2}$ for $4 \mathrm{~h}$ at $4^{\circ} \mathrm{C}$. Bound IFN was then crosslinked to receptors with $1 \mathrm{mM}$ disuccinimidyl suberate, and cell extracts subjected to $7.5 \%$ SDS-PAGE. The film was exposed to XAR (Eastman Kodak Co.) film for $8 \mathrm{~d}$. Lane 1, controls without IFN pretreatment; lanes 2-5 represent cross-linking at $0 \mathrm{~h}, 6 \mathrm{~h}, 12 \mathrm{~h}$, and $22 \mathrm{~h}$ after IFN pretreatment; lane 6 , after $22 \mathrm{~h}$ of recovery incubation, cells were re-treated with $1,000 \mathrm{U} / \mathrm{ml}$ of IFN $\alpha_{2}$ at $37^{\circ} \mathrm{C}$ for $3 \mathrm{~h}$; lane 7, control cells with binding incubation including a 100-fold excess of unlabeled IFN $\alpha_{2}$. bound with ${ }^{125}$ I-IFN $\alpha_{2}$, the prebound ligand is covalently linked to the moieties of the receptor which are responsible for the binding of ligand. Subsequent disruption of the plasma membrane by cell lysis buffer releases the ${ }^{125}$ I-IFN $\alpha_{2}$-receptor complexes, which can be resolved and visualized by SDS-PAGE and autoradiography. This analysis yields sensitive qualitative information on the expression of cell surface IFN receptors. TBL, when preincubated for a period of $3 \mathrm{~h}$ with IFN $\alpha_{2}$ at a concentration of $1,000 \mathrm{U} / \mathrm{ml}$, showed ligand-induced downregulation of IFN $\alpha$ receptors (Fig. 4, lane 2). When incubated in IFN-free RPMI medium, following receptor downregulation, cells showed a gradual recovery of ${ }^{125}$ I-IFN $\alpha_{2}$ binding activity over a 22 -h period (Fig. 4, lanes 3-5).

The complete recovery of receptors in PBL took $72 \mathrm{~h}$, as demonstrated by cellular binding assays (Fig. 5). In this experiment PBL were pretreated with $1,000 \mathrm{U} / \mathrm{ml}$ of IFN $\alpha_{2}$, and receptor binding activities were measured during the recovery period of $3 \mathrm{~d}$. The pretreated cells showed gradual recovery of binding activity compared to that of the control level over a period of $3 \mathrm{~d}$.

Effect of actinomycin D on recovery of IFN receptor expression. The reappearance of IFN binding during recovery in IFNfree medium can be blocked by the presence of actinomycin $D$ (Fig. 6). Cellular binding assays were performed on these cells in order to generate specific binding curves for the quantitative determination of receptor sites. In this experiment, the control PBL exhibited $480 \pm 70$ receptor sites/cell (Fig. 6, lane 2). With IFN $\alpha_{2}$ pretreatment (followed by acidic PBS wash), both affinitylabeling and cellular binding assays did not detect any receptor expression (Fig. 6, lane 3). These pretreated cells, when allowed to recover in IFN-free medium, exhibited $227 \pm 29$ receptor sites per cell after $22 \mathrm{~h}$ of incubation (Fig. 6, lane 4). However, in the presence of actinomycin D (final concentration at $1 \mu \mathrm{g} / \mathrm{ml}$ ), the recovery of IFN receptor binding was minimal, i.e., $70 \pm 10$ receptor sites/cell. This result (Fig. 6, lane 5) suggests that the recovery of IFN binding activity, following down-regulation, requires messenger RNA (mRNA) synthesis.

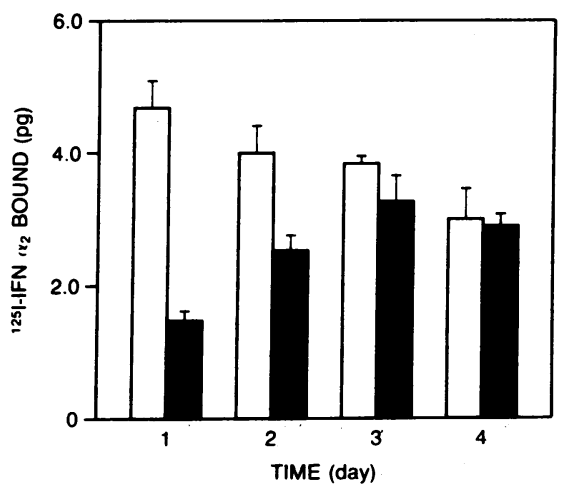

Figure 5. Recovery of IFN receptor binding. PBL were pretreated with $1,000 \mathrm{U} / \mathrm{ml}$ of IFN $\alpha_{2}$ at $37^{\circ} \mathrm{C}$ for $18 \mathrm{~h}$. Cells were washed with acidic PBS (pH 5.5) and allowed to recover in IFN-free RPMI medium at $37^{\circ} \mathrm{C}$ over a period of $3 \mathrm{~d}$. Aliquots of $4 \times 10^{5}$ cells were taken for IFN receptor binding assay with $15 \mathrm{ng} / \mathrm{ml}$ of ${ }^{125} \mathrm{I}-\mathrm{IFN} \alpha_{2}$ at indicated time intervals. Cells, not treated with IFN $\alpha_{2}$ and incubated for the same period of time, were used as controls. Each bar represents the mean of triplicate incubations, with error bars indicating one standard deviation about the mean. Open bar, controls; shaded bar, IFN treated. 

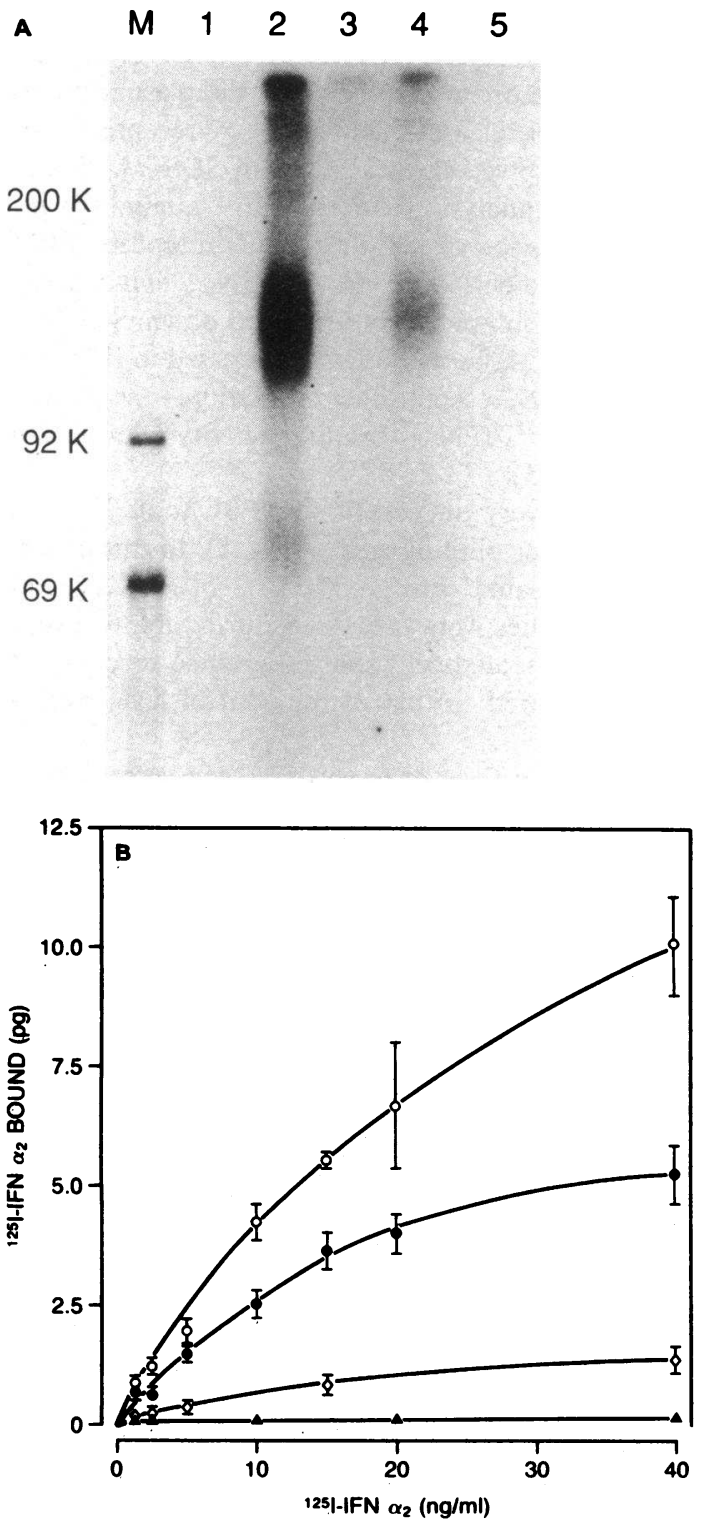

Figure 6. Effect of actinomycin D on the recovery of IFN receptor binding. Freshly isolated PBL were pretreated with $1,000 \mathrm{U} / \mathrm{ml}$ of IFN $\alpha_{2}$ for $3 \mathrm{~h}$ at $37^{\circ} \mathrm{C}$. The cells were washed with acidic PBS (pH 5.5) to dissociate any prebound unlabeled IFN $\alpha_{2}$. The cells were allowed to recover in IFN-free RPMI medium for $22 \mathrm{~h}$ at $37^{\circ} \mathrm{C}$, with or without the presence of actinomycin $\mathrm{D}(1 \mu \mathrm{g} / \mathrm{ml})$. $(A) 5 \times 10^{6}$ cells were taken for binding with ${ }^{125} \mathrm{I}$-IFN $\alpha_{2}$, crosslinking with dissucinimidyl suberate and SDS-PAGE as described in Fig. 5. Group 1, control cells with binding incubation containing a 100 -fold excess of unlabeled IFN. Group 2, control cells without IFN or actinomycin D treatment. Group 3, cells pretreated with IFN without recovery incubation. Group 4, cells pretreated with IFN, recovered for $22 \mathrm{~h}$. Group 5, cells pretreated with IFN, recovered for $22 \mathrm{~h}$ in the presence of actinomycin D. $(B)$ Cellular binding assays were performed on each group of cells described in $(A)$. ०, Group 2; $\wedge$, Group 3; •, Group 4; $\diamond$, Group 5.

In vivo studies on IFN receptor expression. IFN $\alpha_{2}$ receptor binding was monitored in patients on IFN $\alpha_{2}$ therapy for either papilloma virus infections or acute lymphoblastic leukemia. The age of the patients ranged from 7 to $34 \mathrm{yr}$. They were treated daily with IFN subcutaneously, as described in Methods. The number of IFN $\alpha$ receptors on the PBL of a patient with condyloma acuminata (due to papilloma virus infection) was $834 \pm 160$ per cell prior to IFN therapy (Fig. 7). With the progression of therapy, the receptor number decreased to $262 \pm 42$, $72 \pm 8$, and $220 \pm 40$ on day 5 , day 19 , and day 25 of IFN therapy respectively (Fig. 7). A similar reduction in IFN receptor binding to PBL during IFN therapy was also observed in the other two patients with either papilloma virus infection or acute lymphoblastic leukemia (Table II). Generally, following 2-5 d of IFN therapy, the receptor numbers decreased by $40-70 \%$, i.e., from $834 \pm 160$ to $262 \pm 42,276 \pm 50$ to $152 \pm 19$, and $705 \pm 100$ to $413 \pm 70$ sites per cell, respectively (Table II).

\section{Discussion}

IFNs are a unique group of glycoproteins that possess potent antiviral, antiproliferative, and immunoregulatory functions (1, 2). As a consequence, they have been used therapeutically in various preliminary clinical trials. Clinical efficacy of IFN $\alpha$ against several infectious diseases (influenza virus, papilloma virus, herpes zoster, and hepatitis B) has been reported $(3,23-$ 26). More recently, antineoplastic activity of IFN has been demonstrated in patients with non-Hodgkin's lymphoma, myeloma, and, most dramatically, hairy cell leukemia (27-29). Most of these studies have focused on the pharmacokinetics, side effects and toxicities of IFN, or clinical responses of the patients. Many of the basic mechanisms involved in the induction by IFN of antiviral and antineoplastic activities in vivo remain to be elucidated.

In vitro studies on cultured cell lines have shown that IFNs elicit antiviral and antineoplastic activities by binding to specific high affinity cell surface receptors (4). Events following the binding of IFN have been the subject of intensive investigation. These events culminate, in part, in the induction of 2,5A synthetase, protein kinase and possibly endonuclease enzymes $(1,2,30)$. It has also been reported that both IFN $\alpha$ and IFN $\gamma$ are internalized and degraded intracellularly subsequent to binding $(7,8)$. It is not known whether internalization is necessary for the biological activity of IFN. In fact, it has been demonstrated that inhibition

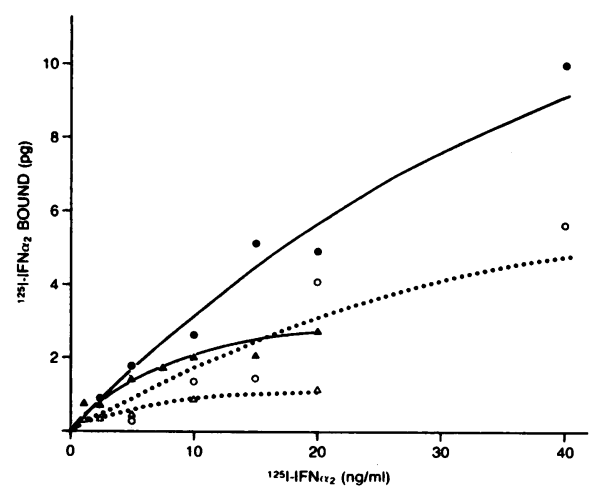

Figure 7. IFN receptor binding in vivo in PBL during IFN therapy. The patient is a 34-yr-old white female with severe condyloma acuminata with cutaneous disseminations. She was treated with IFN $\alpha_{2}$, and IFN receptor binding studies were performed as described in Methods. Nonspecific binding represented $50 \%$ of total binding. Points are the means of duplicate or triplicate incubations for each ${ }^{125} \mathrm{I}-\mathrm{IFN} \alpha_{2}$ concentration, with maximum deviations of $\pm 10 \%$ about the mean. Binding studies were done before (๑), at day $5(0)$, day $19(\Delta)$, and day 25 (ム) of IFN therapy. 


\begin{tabular}{llllllll}
\hline & & & & & \multicolumn{2}{l}{ Receptor number } \\
\cline { 6 - 8 } Patient & Age & Sex & Diagnosis & $\begin{array}{l}\text { Doses } \\
\text { given }\end{array}$ & Basal & IFN & Reduction \\
\hline A & $34 \mathrm{yr}$ & $\mathrm{F}$ & Condyloma acuminata & 5 & $834 \pm 160$ & $262 \pm 42$ & $\downarrow$ \\
B & $16 \mathrm{yr}$ & M & A.L.L. Papillomavirus & 5 & $276 \pm 50$ & $152 \pm 19$ & $\downarrow 45 \%$ \\
C & $7 \mathrm{yr}$ & F & A.L.L. & 2 & $705 \pm 100$ & $413 \pm 70$ & $\downarrow 42 \%$
\end{tabular}

Patient A is a 34-yr-old white female with condyloma acuminata with severe cutaneous dissemination. She had no underlying immune disorder. Patient B is a 16-yr-old white male with acute lymphoblastic leukemia (A.L.L.), diagnosed 1 yr before IFN therapy. He received standard chemotherapy and had been in remission since. He developed persistent flat warts (papilloma virus infection) which were resistant to conventional therapy. Patient $\mathrm{C}$ is a 7-yr-old white female with A.L.L. She received standard chemotherapy, and was initially in remission but subsequently developed relapse of the leukemic disease. At the time of IFN therapy, she had leukemic cells in her bone marrow but not in the blood circulation. The IFN binding studies were done before the initiation of intensive chemotherapy. IFN $\alpha$ receptor bindings in PBL (in triplicates) were studied in patients before and during the course of IFN therapy. The binding data were analysed by LIGAND to determine the numbers of receptors. F, female; $M$, male.

of internalization of IFN-receptor complexes with cytochalasin does not affect 2,5A synthetase induction in Daudi (lymphoblastoid) cells (7), and an IFN-resistant variant of Daudi cells has been shown to internalize ${ }^{125} \mathrm{I}$-IFN $\alpha_{2}$ similar to the IFNsensitive Daudi (10).

In this paper, we have demonstrated that human PBL and TBL, when pretreated in vitro with IFN $\alpha_{2}$, show a marked reduction in receptor binding of ${ }^{125} \mathrm{I}$-IFN $\alpha_{2}$. The reduced binding represents downregulation of IFN receptor expression at the cell surface in these freshly isolated lymphocytes. This observation is in accord with findings in Daudi, T98G, and other cultured cell lines (10-12). Interestingly, when resting lymphocytes were incubated in IFN-free medium subsequent to downregulation, IFN binding activities gradually recovered over a period of 72 $h$ (Figs. 4, 5). The recovery of receptor binding was blocked by actinomycin D (Fig. 6) and thus synthesis of new receptor mRNA might be required for this recovery.

The in vivo studies reported here on patients receiving IFN therapy revealed a similar phenomenon of reduction in IFN binding (Fig. 7). Concurrent with the progression of therapy, the IFN binding activities in the patients' PBL were further reduced. This reduction in binding most likely results from IFNinduced downregulation of IFN receptor expression in vivo during IFN therapy. However, we cannot exclude the possibility of a loss of an IFN-responsive cellular population in the peripheral circulation during therapy. This latter explanation seems less likely, as our in vivo findings were entirely similar to those of the in vitro observations on downregulation.

The events occurring at the cell surface receptor level are undoubtedly important in the regulation of IFN actions. Two recent studies have demonstrated that natural killer cell activity from patients under continuous IFN therapy are reversibly refractory to in vitro stimulations by IFN $(31,32)$. Similarly, a reversible resistance to IFN action has been observed in vitro in transformed mouse fibroblasts during continuous IFN exposure (33). Gupta et al. demonstrated that the IFN-induced synthesis of specific polypeptides in human cells reaches a maximum within the first few hours of prolonged IFN treatment. This is followed by a refractory period during which there is a decline in IFN-induced protein synthesis (34). These observations of hyporesponsive states during prolonged, continuous exposure to IFN could be explained by downregulation of IFN receptor expression at the cell surface. On the basis of our in vivo and in vitro findings on the IFN-induced regulation of IFN receptor expression, together with that of the aforementioned hyporesponsiveness of cells during continuous IFN treatment, it appears that an interval treatment schedule for IFN therapy might be more appropriate than a continuous one, as it allows recovery of cell surface IFN receptors necessary for further binding interaction with exogenously administered interferon.

\section{Acknowledgments}

The authors wish to thank Drs. P. Trotta and T. Nagabhushan (Schering Corp.) for supplying Hu-IFN $\alpha_{2}$.

Dr. Williams is a Medical Research Council (MRC) (Canada) Scholar. Dr. Lau is an MRC Fellow. This work was supported by grants from the National Cancer Institute of Canada and Pediatric Consultants, The Hospital for Sick Children.

\section{References}

1. Stiehm, E. R., L. H. Kronenberg, H. M. Rosenblatt, Y. Bryson, and T. C. Merigan. 1982. Interferon: immunobiology and clinical significance. Ann. of Int. Med. 96:80-93.

2. DeMayer, E., and H. Schellekens, editors. 1983. The Biology of the Interferon System. Elsevier/North Holland, New York. 549 pp.

3. Cesario, T. C. 1983. The clinical implications of human interferons. Med. Clin. N. Am. 67:1147-1162.

4. Zoon, K. C., and H. Arnheiter. 1984. Studies of the interferon receptors. Pharmac. Ther. 24:259-278.

5. Standaert, M. L., and R. J. Pollet. 1984. Equilibrium model for insulin-induced receptor down-regulation. J. Biol. Chem. 259:2346-2354.

6. Carpenter, J., and S. Cohen. 1979. Epidermal growth factor. Annu. Rev. Biochem. 48:193-216.

7. Branca, A. A., C. R. Faltynek, S. B. D'Alessandro, and C. Baglioni. 1982. Interaction of interferon with cellular receptors: internalization and degradation of cell-bound interferon. J. Biol. Chem. 257:1329113296.

8. Anderson, P., Y. K. Yip, and J. Vilcek. 1983. Human interferon gamma is internalized and degraded by cultured fibroblasts. J. Biol. Chem. 258:6497-6502.

9. Branca, A. A., and C. Baglioni. 1982. Down-regulation of the interferon receptor. J. Biol. Chem. 257:13197-13200.

10. Hannigan, G. E., D. R. Gewert, and B. R. G. Williams. 1984. Characterization and regulation of $\alpha$-interferon receptor expression in interferon-sensitive and -resistant human lymphoblastoid cells. J. Biol. Chem. 259:9456-9460.

11. Sarker, F. H., and S. L. Gupta. 1984. Interferon receptor interaction: internalization of interferon $\alpha_{2}$ and modulation of its receptor on human cells. Eur. J. Biochem. 140:461-467. 
12. Zoon, K. C., H. Arnheiter, D. Z. Nedden, D. J. P. Fitzgerald, and M. C. Willingham. 1983. Human interferon alpha enters cells by receptor-mediated endocytosis. Virology. 130:195-203.

13. Hannigan, G. E., E. N. Fish, and B. R. G. Williams. 1984. Modulation of human interferon- $\alpha$ receptor expression by human interferonr. J. Biol. Chem. 259:8084-8086.

14. Branca, A. A., and C. Baglioni. 1981. Evidence that types I and II interferons have different receptors. Nature (Lond.). 294:768-770.

15. Williams, B. R. G., and S. E. Read. 1981. Detection of elevated levels of the interferon-induced enzyme 2,5-A synthetase, in infectious diseases and on parturition. In The Biology of the Interferon System. E. DeMaeyer, G. Galasso, and H. Schellekens, editors. Elsevier/North Holland, New York, 111-114.

16. Gordon, D. S., B. M. Jones, S. E. Browning, T. J. Spira, and D. N. Lawrence. 1982. Persistent polyclonal lymphocytosis of B lymphocytes. N. Engl. J. Med. 307:232-236.

17. Hannigan, G. E., G. R. Gewert, E. N. Fish, S. E. Read, and B. R. G. Williams. 1983. Differential binding of human interferon- $a$ subtypes to receptors on lymphoblastoid cells. Biochem. Biophys. Res. Commun. 110:537-544.

17a. Hannigan, G. E., A. S. Lau, and B. R. G. Williams. 1986. Differential human interferon-alpha receptor expression on proliferating and non-proliferating cells. Eur. J. Biochem. In press.

18. Dahlquist, F. W. 1978. The meaning of Scatchard and Hill plots. Methods Enzymol. 48:270-299.

19. Scatchard, G. 1949. The attraction of protein for small molecules and ions. Ann. N.Y. Acad. Sci. 51:660-672.

20. Munson, P. J., and D. Rodbard. 1980. LIGAND: A versatile computerized approach for characterization of ligand binding systems. Anal. Biochem. 107:220-239.

21. Faltynek, C. R., A. A. Branca, S. McCandless, and C. Baglioni. 1983. Characterization of an interferon receptor on human lymphoblastoid cells. Proc. Natl. Acad. Sci. USA. 80:3269-3273.

22. Sarker, F. H., and S. L. Gupta. 1984. Receptors for human $\gamma$ interferon: Binding and crosslinking of ${ }^{125}$ I-labeled recombinant human $\gamma$ interferon to receptors on WISH cells. Proc. Natl. Acad. Sci. USA. 81: $5160-5164$.

23. Merigan, T., K. Rand, R. Polland, P. Abdallah, G. Jordan, and R. Fried. 1978. Human leukocyte interferon for the treatment of herpes zoster in patients with cancer. N. Engl. J. Med. 298:981-987.
24. Greenberg, H., R. Pollard, L. Lutwick, P. Gregory, W. Robinson, and T. Merigan. 1976. Effect of human leukocyte interferon on hepatitis B virus infections in patients with chronic active hepatitis. $N$. Engl. $J$. Med. 295:517-522.

25. Desmyter, J., M. Ray, J. DeGroute, and V. Desmet. 1976. Administration of human fibroblast interferon in chronic hepatitis $B$ virus infection. Lancet. 2:645-647.

26. Haglund, S., P. G. Lundquist, K. Cantell, and H. Strander. 1981. Interferon therapy in juvenile laryngeal papillomatosis. Arch. Oto-rhinolaryngol. 107:327-332.

27. Gutterman, J., G. Blumenschein, R. Alexanian, H. Yap, A. Buzdar, F. Cabanillas, G. Hortobagyi, E. Hersh, S. Rasmussen, M. Harmon, M. Kramer, and J. Pestka. Leukocyte interferon induced tumor regression in human metastatic breast cancer, multiple myeloma and malignant lymphoma. Ann. Int. Med. 93:399-406.

28. Quesada, J. R., J. Reuben, J. T. Manning, E. M. Hersh, and J. U. Gutterman. 1984. Induction of remission in hairy cell leukemia with alpha interferon. N. Engl. J. Med. 310:15-18.

29. Quesada, J. R., E. M. Hersh, and J. U. Gutterman. 1984. Biologic therapy of hairy cell leukemia. Semin. Oncol. 11(Suppl. 2):507-510.

30. Williams, B. R. G., and E. N. Fish. 1985. Interferon and viruses: in vitro studies. In Interferons: Their Impact in Biology and Medicine. J. Taylor-Papadimitriou, editor. Oxford University Press. 40-60.

31. Einhorn, S., H. Blomgren, and H. Strander. 1980. Interferon and spontaneous cytotoxicity in man: enhancement of spontaneous cytotoxicity in patients receiving human leukocyte interferon. Int. J. Cancer. 26:419-428.

32. Golub, S. H., P. D'Amore, and M. Rainey. 1982. Systemic administration of human leukocyte interferon to melanoma patients. II. Cellular events associated with changes in natural killer cytotoxicity. $J$. Nat. Cancer Inst. 68:711-717.

33. Chany, C., and M. Vignal. 1970. Effect of prolonged interferon treatment on mouse embryonic fibroblasts transformed by murine sarcoma virus. J. Gen. Virol. 7:203-210.

34. Gupta, S. L., B. Y. Rubin, and S. L. Holmes. 1981. Regulation of interferon action in human fibroblasts: transient induction of specific proteins and amplification of antiviral response by actinomycin D. $\mathrm{Vi}$ rology. 111:331-340. 